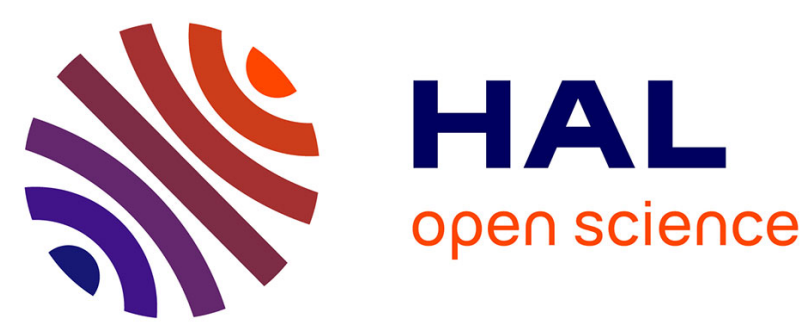

\title{
Repeat surgery in HNF1alpha-inactivated adenomatosis
}

Charles Balabaud, Christophe Laurent, Nora Frulio, Saint Paul Marie Christine, Brigitte Le Bail, Laurent Possenti, Jean Frédéric Blanc, Laurence Chiche, Paulette Bioulac-Sage

\section{To cite this version:}

Charles Balabaud, Christophe Laurent, Nora Frulio, Saint Paul Marie Christine, Brigitte Le Bail, et al.. Repeat surgery in HNF1alpha-inactivated adenomatosis. Clinics and Research in Hepatology and Gastroenterology, 2019, 43, pp.460 - 467. 10.1016/j.clinre.2018.11.001 . hal-03487720

\section{HAL Id: hal-03487720 \\ https://hal.science/hal-03487720}

Submitted on 20 Dec 2021

HAL is a multi-disciplinary open access archive for the deposit and dissemination of scientific research documents, whether they are published or not. The documents may come from teaching and research institutions in France or abroad, or from public or private research centers.
L'archive ouverte pluridisciplinaire HAL, est destinée au dépôt et à la diffusion de documents scientifiques de niveau recherche, publiés ou non, émanant des établissements d'enseignement et de recherche français ou étrangers, des laboratoires publics ou privés.

\section{(ㄷ)(1) $\$$}

Distributed under a Creative Commons Attribution - NonCommerciall 4.0 International 


\title{
Repeat surgery in HNF1alpha-inactivated adenomatosis
}

Charles Balabaud ${ }^{1}$, Christophe Laurent $^{2}$, Nora Frulio ${ }^{3}$, Marie Christine Saint Paul ${ }^{4}$, Brigitte

Le Bail ${ }^{1,5}$, Laurent Possenti ${ }^{6}$, Jean Frédéric Blanc ${ }^{1,6}$, Laurence Chiche ${ }^{2}$, Paulette BioulacSage $^{1}$

\author{
${ }^{1}$ Charles Balabaud, \\ Inserm, UMR1053 Bordeaux Research In Translational Oncology, BaRITOn, F-33076 \\ Bordeaux, France \\ Université de Bordeaux, F-33076 Bordeaux, France
}

Tel 33557571771

Fax 33556514077

charles.balabaud@u-bordeaux.fr

\section{${ }^{2}$ Christophe Laurent}

Service de Chirurgie Digestive et Endocrinienne

Centre Médico Chirurgical Magellan, Haut-Lévêque Hospital , CHU Bordeaux, F 33604

Pessac, France

\section{${ }^{3}$ Nora Frulio}

Department of Radiology Magellan 2, Haut Lévêque hospital, CHU Bordeaux , F33604

Pessac, France

\section{${ }^{4}$ Marie Christine Saint Paul}

Pathology Department, Pasteur Hospital, CHU Nice, F-06002 Nice, France 


\section{${ }^{1,5}$ Brigitte Le Bail}

Inserm, UMR1053 Bordeaux Research In Translational Oncology, BaRITOn, F-33000

Bordeaux, France

Université de Bordeaux, F-33076 Bordeaux, France

Pathology Department, Pellegrin Hospital, CHU Bordeaux, F 33076 Bordeaux France

\section{${ }^{6}$ Laurent Possenti}

Department of Hepato-Gastroenterology and Digestive Oncology, Haut-Lévêque Hospital, CHU Bordeaux, F-33604 Pessac, France

\section{${ }^{1,6}$ Jean Frédéric Blanc}

Inserm, UMR1053 Bordeaux Research In Translational Oncology, BaRITOn, F-33000

Bordeaux, France

Université de Bordeaux, F-33076 Bordeaux, France

Department of Hepato-Gastroenterology and Digestive Oncology, Haut-Lévêque Hospital,

CHU Bordeaux, F-33604 Pessac, France

\section{${ }^{2}$ Laurence Chiche}

Service de Chirurgie Digestive et Endocrinienne

Centre Médico Chirurgical Magellan, Haut-Lévêque Hospital ,CHU Bordeaux, F 33604

Pessac, France

\section{${ }^{1}$ Paulette Bioulac-Sage}

Inserm, UMR1053 Bordeaux Research In Translational Oncology, BaRITOn, F-33000

Bordeaux, France

Université de Bordeaux, F-33076 Bordeaux, France 
Electronic word count for main body: 2399, abstract 207

Number of figures: 1 and tables: 4

Number of pages 14

\section{List of abbreviations}

Hepatocellular adenoma (HCA)

HNF1a-inactivated HCAs (H-HCA),

HNF1a-inactivated adenomatosis (H-adenomatosis)

Inflammatory HCAs (IHCA),

$\beta$-catenin activated HCA (b-HCA),

$\beta$-catenin activated and inflammatory HCAs (b-IHCA)

\section{Conflict of interest: No}

Financial support: No

$\mathrm{CB}$, PBS design the study and wrote the paper

CL, JFB, LC, NF, followed the patients

BLB, MCSP, and PBS performed the immunohistochemistry

LP is in charge of the data base

$\mathrm{CB}$ and PBS reviewed the slides

\section{Acknowledgements:}


We thank Pr J Zucman-Rossi for performing the molecular analysis, the Réseau National Centre de Ressources Biologiques (CRB) Foie and the Bordeaux Liver Bank BB-0033-00036 for contributing to the tissue collection

\begin{abstract}
Background \& Aims. Stopping oral contraceptives following nodule detection usually prevents further hepatocellular growth (HCA); rare cases of growth have been reported after surgery.

The aim of the study was to review our resected HCA cases and their outcomes and more specifically, growth.
\end{abstract}

Methods. We retrieved all HCA cases that required a second intervention and HCA growth cases of none resected HCA after resection of one or several HCAs.

Results. Out of the 210 resected classified HCA cases, a second resection was performed in 5 cases, 4 of which were in women with HNF1alpha-inactivated adenomatosis (Hadenomatosis) and had a favorable outcome. The fifth case was the occurrence of an inflammatory HCA, 3 years after resection of a previous one. Of the 65 resected HNF1 $\alpha$ inactivated HCAs (H-HCAs), the nodules that remained continued to increase very slowly in 3 adenomatosis cases. After surgery, the liver became dysmorphic years later in one case, and the nodules grew but not significantly in another case. After the diagnosis of adenomatosis, progressive growth leads to surgery 12 years later in the last case.

Conclusion. These results confirm that, in rare $\mathrm{H}$-adenomatosis, size of nodules may increase very slowly, probably in part through coalescence of micro H-HCAs and leading occasionally to a second resection. 
Key words: Hepatocellular adenoma; HNF1alpha -inactivated hepatocellular adenoma; adenomatosis; liver surgery

\section{Key points}

- Stopping oral contraceptives following nodule detection usually prevents further hepatocellular adenoma (HCA) growth.

- Rare cases of HCA growth have been reported leading eventually to a second intervention

- Growth is only observed in rare HNF1 alpha-inactivated adenomatosis

- Size of nodules may increase, probably in part through coalescence of micro H-HCAs.

- A second intervention due to HCA expansion has to be evaluated; liver transplantation is still not an option. 


\section{Background}

Hepatocellular adenoma (HCA) occurs mainly in women taking oral contraceptives (OC) ${ }^{1-6}$. Additional factors such as obesity also play a role ${ }^{7}$. Outside the context of emergency, classically, surgery is performed for $\mathrm{HCA} \geq 5 \mathrm{~cm}$ to prevent hemorrhage and malignant transformation complications ${ }^{1-6}$; HCA growth is rarely observed after stopping OC ${ }^{1-6}$. However, there are some cases of re-intervention reported in the literature due to de novo growth ${ }^{2}$. Unfortunately, there is no indication on the subtype of these growing HCAs that may require a second resection. In this work, our aim was to study and provide a better overview of the phenotype of growing HCA during follow-up leading, occasionally, to re-intervention.

\section{Material and methods}

Between January 1988 and September 2017, 218 patients had resection for one or several HCAs in our department. All HCAs were classified using the phenotype classification ${ }^{8-10}$. There were 65 HNF1alpha inactivated HCAs (H-HCA), 71 Inflammatory HCAs (IHCA), 23 $\beta$-catenin activated HCA (b-HCA), $30 \beta$-catenin activated and inflammatory HCAs (b-IHCA), 21 HCAs overexpressing ASS $1^{11}$. One patient with an ASS1+HCA had also 2 IHCA and was counted in the 71 IHCA list. Finally, 8 patients had unclassifiable HCAs (UHCA) due to massive necrosis and/or hemorrhage.

In our database, we retrieved surgical cases with single nodule, multiple nodules and adenomatosis (10 or more nodules identified by imaging) as well as cases with recurrence of new nodules or growth during follow up occurring after or before resection.

We retrieved cases with growth leading to re-intervention in 5 out of the 8 cases (excluding cases with pre-established surgery in 2 steps and cases with growth depending on malignant transformation). 
No strict guidelines concerning the definition of growth observed on MRI was applied in this retrospective study. The rhythm of follow-up is also related to multiple factors (table 1). This study was approved by the local committee of "Direction de la recherche clinique et de l'innovation" Bordeaux University hospital, Bordeaux Liver Biobank BB-0033-00036.

\section{Results}

The total number of resected HCAs according to a specific phenotype, number of nodules before surgery and patients with nodules still present after surgery is presented in table 2 . It is interesting to note that growth before or after surgery leading or not to re-intervention was essentially observed in the group of H-HCA (table 2) and specifically those with adenomatosis. In our series of $65 \mathrm{H}-\mathrm{HCAs}, 27$ cases had developed a single nodule, 23 cases with multiple nodules, and 15 cases with adenomatosis. In 24 cases, nodules were left over after resection (11 cases of multiple $\mathrm{H}-\mathrm{HCA}$ and 13 cases of $\mathrm{H}$-adenomatosis; table 2). The size of the nodules remained stable or decreased in all H-HCA cases but :

(i) In 3 cases, we observed growth during follow-up but not leading to re-intervention (table 3). In case 166, the biggest nodule in segment I was $20 \mathrm{~mm}$ in 1998, growing slowly (28 $\mathrm{mm}$ in 2000, $35 \mathrm{~mm}$ in 2011); Tumorectomies (segments I, IV and VI) were performed 13 years later (2011) and shown H-HCA nodules measuring 35, 40 and $15 \mathrm{~mm}$, respectively. In case 22, the nodule in segment I was $40 \mathrm{~mm}$ in 1994 and was $75 \mathrm{~mm}$ in 2008; the surgeon was reluctant to remove the nodule for technical reasons. MRI in 2016 showed that the liver was dysmorphic with many steatotic areas with an ill-defined confluent heterogeneous mass and nodules of different size (difficult to measure precisely). A liver biopsy was performed in this specific area. On H\&E, the biopsy contained intermingled tumoral (partly steatotic) and non-tumoral tissue. No fibrosis was detected. Lack of LFABP confirmed the H-HCA subtype. 
In case 122, small H-HCA left over after surgery grew over time but not significantly from 2008 to 2015.

(ii) In $4 \mathrm{H}$-HCA cases, growth lead to re-intervention; the clinical, radiological, surgical

and pathological data of these cases are presented in table 4 . All four patients had Hadenomatosis and without MODY3 or vascular disorders. The second resection was performed after 9 years in two cases, 11 and 23 years, in the other two cases. Interestingly, in one case (case 82), the first resection was a right hepatectomy for an enormous adenomatosis, sparing the left lobe (imaging). Nine years later, new nodules were discovered in the left lobe. On the second resected specimen, at least one nodule was at the margin of first resection.

Finally, in our database, we found only one case of re-intervention not linked to H-HCA phenotype (case 72; table 4). The first resection (right hepatectomy) was performed in 2000 in a 53-year-old woman for a $15 \mathrm{~cm}$ acute hemorrhagic tumor with non-specific pathological criteria; CRP was expressed in the tumoral and non-tumoral liver. In spite of the absence of inflammatory criteria on H\&E the diagnosis of IHCA was raised with the detection of IL6ST mutation. During follow-up, another nodule was discovered which was $15 \mathrm{~mm}$ in 2001, 30 mm in 2003 leading to a segmentectomy. This nodule was a typical IHCA (H\&E, C Reactive protein positivity by immunohistochemistry), also IL6ST mutated.

\section{Discussion}

There is poor information in the literature related to HCA growth. When HCAs are detected, women often stopped OCs following which the nodules growth stopped or their numbers decreased or disappeared ${ }^{4}$. This seems to be the case mainly in IHCAs ${ }^{12}$. In the absence of regression, large nodules $(>5 \mathrm{~cm})$ are usually resected. Growth of unresected nodules $<5 \mathrm{~cm}$ after OC cessation is rare, and therefore not well documented except in case of malignant transformation, mainly in b-HCA ${ }^{13-17}$ or when HCA occurred in specific conditions such as 
an underlying liver disease (NASH, vascular diseases, GSD, etc) ${ }^{14}$. In men, HCAs are resected whatever their size and subtype.

In one of the largest series published ${ }^{2}$, HCAs recurred or increased in size in $9(8 \%)$ patients, aged 19 to 46 years. None of these 9 patients, with a follow-up period ranging from 15 to 134 months, experienced HCA complications. However, two underwent additional surgery for HCA enlargement $>5 \mathrm{~cm}$. On the other hand, regression and even disappearance of HCAs was observed in 4 (9\%) out of the 45 patients with residual HCA after a follow-up period of 130 months (aged $37-59$ years) ${ }^{2}$.

Our study showed that growth occurred, particularly in H-adenomatosis (corresponding to $>10$ nodules by imaging). We observed that true growth occurred in only 1 case (82, table 3$)$. Surprisingly, the massive tumoral section was restricted to the right lobe of the liver ${ }^{19}$ and we noticed that the non-tumoral part, close to, contained multiple undetected micro H-HCAs. Unexpectedly, during follow-up, new nodules appeared in the remaining liver at the border of the resected liver. With time, those micro H-HCAs continued to grow albeit slowly (from undetected to a max of $35 \mathrm{~mm}$ in 9 years) (table 3 case 82 ) leading to a second intervention in another university hospital (Nice). The slow expansion/prolifertaion process is illustrated in the $7 \mathrm{H}$-adenomatosis cases reported in this series (tables 2 and 3) Apart from true growth, it is important to outline that there is an additional possibility to explain the apparent growth. H-adenomatosis are composed of numerous nodules of different sizes and micro H-HCAs (in variable number), some in their immediate vicinity. Micro HHCAs may coalesce with larger ones to form detectable nodules (by imaging) ${ }^{20}$ and may lead, over time, to an apparent growth (Fig 1) ${ }^{21-22}$. Coalescence could be due to arterial diversion more to the tumor than to the normal parenchyma in between two nodules. It is interesting to note that ultimately this arterial diversion may lead, as in case 22 , to a dysmorphic liver. 
Growth due to coalescence of nodules raises the difficult question of its significance in terms of complications and therapeutic strategy. When nodules are $<5 \mathrm{~cm}$ there is no indication for surgery ${ }^{4}$; nevertheless, re-intervention was performed in 2 cases (cases 82, 205; table 4). However, when nodules reach the 5-cm threshold, should they be resected? There are arguments to suggest that H-HCAs are less susceptible to bleeding than IHCAs ${ }^{5-6}$, ASS1+ $\mathrm{HCA}^{11}$ or to malignant transformation compared to b-HCA, leading to the proposal that the 5-cm limit size could be overcome, especially in $\mathrm{H}$-adenomatosis ${ }^{12}$ and in menopaused women. We propose that these patients should be carefully followed-up usually by ultrasound. If growth is very slow, patients should be reassured. In a review dealing with liver transplantation for liver adenomatosis, there were patients transplanted under the label "evolution", meaning patients who had adenomatosis with progression in size or number of adenomas $^{23}$. In our opinion, iterative resection could be a better alternative ${ }^{24}$. Only long-term follow-up of slow-growing $\mathrm{H}$-adenomatosis will indicate if a "wait and see" attitude is reasonable. In addition to the risk of HCC transformation and bleeding, it is relevant to know the natural history of each HCA subtypes. We observed more and more H-HCAs in women far after menopause ${ }^{25}$.

Our series illustrates the rare observation of re-intervention due to the discovery of an IHCA few years after the resection of a previous HCA sharing the same mutation in a woman who has never taken oral contraceptives. In this case it is possible that the nodule that grow during follow-up was present but missed due to its small size. In any case this observation of IHCA is probably exceptional (age of the patient, no oral contraceptives, growth)

This study is retrospective with no protocol to measure exactly the size of the nodules, the limit of detection of nodules, the rhythm and modality of imaging, the decision to operate and re-operate, the criteria to decide when the patient does not need to be followed. Furthermore it does not take into account the radiological improvement in the detection of nodules. In spite 
of that, this study shows clearly that $\mathrm{H}$-adenomatosis is more prone than any other subtypes to growth leading occasionally to re-intervention. This is due to its specificity in terms of the high number of nodules, the weak impact of stopping oral contraceptives on nodule size regression, the possibility of nodules coalescence. Growth as well as the justification of reintervention needs to be confirmed by others.

In conclusion, patients with $\mathrm{H}$-adenomatosis should be carefully followed for a long time period due to the possibility of growth leading occasionally to re-intervention.

\section{References}

1. Bioulac-Sage $\mathrm{P}$, Laumonier $\mathrm{H}$, Couchy $\mathrm{G}$ et al. Hepatocellular adenoma management and phenotypic classification: the Bordeaux experience. Hepatology. 2009;50: 481-489.

2. Dokmak S, Paradis V, Vilgrain V et al. A single-center surgical experience of 122 patients with single and multiple hepatocellular adenomas. Gastroenterology. 2009;137: 1698-1705.

3. European Association for the Study of the Liver. EASL Clinical Practice Guidelines on the management of benign liver tumours. J Hepatol 2016; 65: 386398.

4. Klompenhouwer AJ, Bröker MEE, Thomeer MGJ, Gaspersz MP, de Man RA, IJzermans JNM. Retrospective study on timing of resection of hepatocellular adenoma. Br J Surg. 2017 Aug 30. [Epub ahead of print]

5. Belghiti J, Cauchy F, Paradis V, Vilgrain V. Diagnosis and management of solid benign liver lesions. Nat Rev Gastroenterol Hepatol. 2014 ;11:737-749 
6. Agrawal S, Agarwal S, Arnason T, Saini S, Belghiti J. Management of Hepatocellular Adenoma: Recent Advances. Clin Gastroenterol Hepatol. 2015;13: 1221-1230.

7. Bioulac-Sage P, Taouji S, Possenti L, Balabaud C. Hepatocellular adenoma subtypes: the impact of overweight and obesity. Liver Int. 2012;32: 1217-1221.

8. Bioulac-Sage P, Rebouissou S, Thomas C. et al. Hepatocellular adenoma subtype classification using molecular markers and immunohistochemistry. Hepatology. 2007; 46: 740-748.

9. Bioulac-Sage P, Sempoux C, Balabaud C. Hepatocellular Adenomas: Morphology and Genomics. Gastroenterol Clin North Am. 2017; 46: 253-272.

10. Bioulac-Sage P, Sempoux C, Balabaud C. Hepatocellular adenoma: Classification, variants and clinical relevance. Semin Diagn Pathol. 2017;34:112125.

11. Henriet E, Hammoud AA, Dupuy JW et al. Argininosuccinate synthase 1 (ASS1): a marker of unclassified hepatocellular adenoma and high bleeding risk. Hepatology. 2017;66:2016-2028

12. Sinclair M, Schelleman A, Sandhu D, Angus PW. Regression of hepatocellular adenomas and systemic inflammatory syndrome after cessation of estrogen therapy.

Hepatology. 2017;66:989-691.

13. Zucman-Rossi J, Jeannot E, Nhieu JT et al. Genotype-phenotype correlation in hepatocellular adenoma: new classification and relationship with HCC. Hepatology. 2006;43:515-524. 
14. Sempoux C, Paradis V, Komuta M et al. Hepatocellular nodules expressing markers of hepatocellular adenomas in Budd-Chiari syndrome and other rare hepatic vascular disorders. J Hepatol. 2015; 63:1173-1180.

15. Sempoux C, Balabaud C, Bioulac-Sage P. Malignant transformation of hepatocellular adenoma. Hepatic Oncology. 2014: 421-431

16. Sempoux C, Bisig B, Couchy G, Balabaud C, Zucman-Rossi J, Bioulac-Sage P. Malignant transformation of a $\beta$-catenin inflammatory adenoma due to an S45 $\beta$-catenin-activating mutation present 12 years before. Hum Pathol. 2017; $62: 122-125$.

17. Sempoux C, Balabaud C, Paradis V, Bioulac-Sage P. Hepatocellular nodules in vascular liver diseases. Virchows Arch. 2018 May 26. [Epub ahead of print]

18. Frulio N, Chiche L, Bioulac-Sage P, Balabaud C. Hepatocellular adenomatosis: what should the term stand for! Clin Res Hepatol Gastroenterol. 2014;38: 132136.

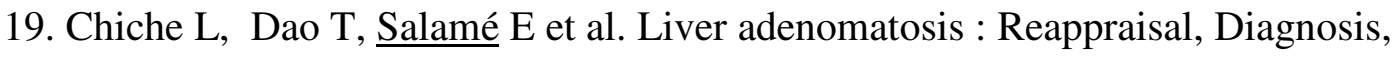
and Surgical Management. Eight New Cases and Review of the Literature. Ann Surg.2000;231:71-84

20. Laumonier H, Bioulac-Sage P, Laurent $\mathrm{C}$ et al. Hepatocellular adenomas: magnetic resonance imaging features as a function of molecular pathological classification. Hepatology. 2008 ; 48:808-818. Erratum in: Hepatology. 2008; 48:1356.

21. Lepreux S, Laurent C, Blanc JF et al. The identification of small nodules in liver adenomatosis. J Hepatol. 2003;39:77-85. 
22. Balabaud C, Laurent C, Le Bail B, et all . Unexpected discovery of small HNF1 $\alpha$-inactivated hepatocellular adenoma in pathological specimens from patients resected for liver tumours. Liver Int. 2017 Dec 19. [Epub ahead of print]

23. Chiche L, David A, Adam R et al. Liver transplantation for adenomatosis: European experience. Liver Transpl. 2016 ;22:516-526.

24. Laurent A, Dokmak S, Nault JC et al. European experience of 573 liver resections for hepatocellular adenoma: a cross-sectional study by the AFC-HCA2013 study group. HPB (Oxford). 2016;18:748-755.

25. Klompenhouwer AJ, Sprengers D, Willemssen FE, Gaspersz MP, Ijzermans JN, De Man RA. Evidence of good prognosis of hepatocellular adenoma in postmenopausal women. J Hepatol 2016; 65: 1163-1170.

\section{Figure Legends}

Fig 1.

This patient (case 53) has multiple H-HCA (adenomatosis). After a first resection in 2001, it shows two close H-HCAs on H\&E (left) with a small subcapsular nodule (A) close to a large nodule (B). A second resection was performed in 2010. On this LFABP staining (right), showing lack of LFABP in HCA, several H-HCA nodules are close to each other giving the impression of a single large one.

NT non tumoral liver. 

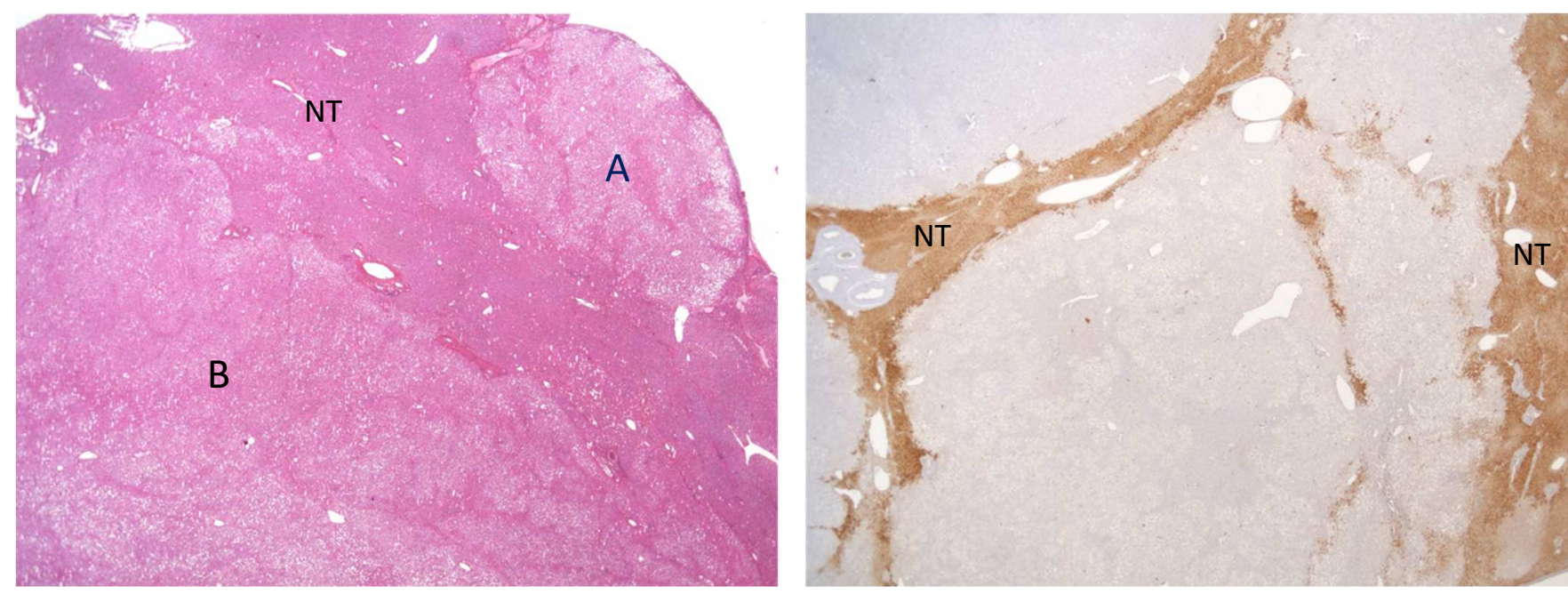


\section{HCA guidelines in Bordeaux liver center}

Rule: No follow-up after a satisfactory control at 2 years. This rule has been applied recently (2016). An ultra sound is recommended at 5 and 10 years. Exceptions - Underlying liver disease : GSD ; vascular disease etc - incomplete resection - HCA with malignant transformation. Follow-up like in HCC micro HCA (surgical specimen): in nodules remained undetected after 2 controls

No resection ${ }^{2}$

Follow -up depends on size ( $>$ or $<2 \mathrm{~cm}$ ) evolution during time (growth, stability or decrease).

Discovery of multiple nodules/ adenomatosis ${ }^{1}$

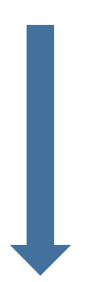

Multiple nodules/adenomatosis left after resection ${ }^{2}$
All large nodules $(>5 \mathrm{~cm})$ are candidates for resection.

All cases are followed as long as HCA continue to grow. Follow-up is stopped when size decreases and become smaller than $1 \mathrm{~cm}$. with a control years later (5). When size remains stable they are followed but with longer time interval

\footnotetext{
${ }^{1}$ stop OC

2 ; decision to operate or not (multidisciplinary liver team ; surgeon, radiologist, hepatologist, pathologist ) depends on age, sex, size, location, etiology, mode of discovery, eventually subtypes (imaging, biopsy) .Major importance to know the subtype (immuno histochemistry
} 
Table 2 - HCA with detectable nodules (imaging) still present in the liver after resection

\begin{tabular}{|c|c|c|c|c|c|}
\hline Subtype & $\mathrm{H}-\mathrm{HCA}$ & IHCA & b-IHCA & b-HCA & ASS1+ HCA \\
\hline Number of patients & 65 & 71 & 30 & 23 & $21 * *$ \\
\hline Solitary Nodule & 27 & 44 & 20 & 17 & 9 \\
\hline Multiple nodules $(<10)$ & 23 & 21 & 8 & 4 & 10 \\
\hline Pts with nodules left over after resection & $11\left(1^{*}\right)$ & $13(1 *)$ & $6\left(1^{*}\right)$ & 3 & $4\left(2^{*}\right)$ \\
\hline follow up at 1 year & 3 & 2 & 1 & 1 & 1 \\
\hline follow up at 2 years & 4 & 5 & 2 & 0 & 1 \\
\hline follow up at 5 years & 3 & 5 & 2 & 2 & 0 \\
\hline adenomatosis $\geq 10$ & 15 & 6 & 2 & 2 & 2 \\
\hline Pts with nodules left over after resection & $13\left(3^{*}\right)$ & $6\left(1^{*}\right)$ & 2 & 2 & 2 \\
\hline follow up at 1 year & 2 & 2 & 0 & 1 & 1 \\
\hline follow up at 2 years & 2 & 3 & 1 & 0 & 1 \\
\hline follow up at 5 years & 6 & 0 & 1 & 1 & 0 \\
\hline re intervention & 4 & 1 & 0 & 0 & 0 \\
\hline growth & 3 & 0 & 0 & 0 & 0 \\
\hline
\end{tabular}

*NA data for follow up $* *$ one patient is in the IHCA list Pts: patient 
Table3 - H-HCA adenomatosis growth during follow-up not leading to reintervention

\begin{tabular}{|c|c|c|c|c|c|c|c|c|}
\hline $\begin{array}{l}\text { Patient } \\
\text { ID }\end{array}$ & $\begin{array}{l}\text { Sex / } \\
\text { year of } \\
\text { birth/age }\end{array}$ & $\begin{array}{l}\text { OC } \\
\text { Yes (years)/no }\end{array}$ & $\begin{array}{l}\text { Date /age patient } \\
\text { location, number } \mathrm{n} / \\
\text { size }(\mathrm{mm})\end{array}$ & $\begin{array}{l}\text { Year surgery/ } \\
\text { Age patient / type } \\
\text { surgery }\end{array}$ & $\begin{array}{l}\text { Resection } \\
\text { location, number } \\
\mathrm{n} / \text { size }(\mathrm{mm})\end{array}$ & $\begin{array}{l}\text { Theoretica } \\
\text { I number } n \\
\text { left in the } \\
\text { liver } \\
\text { location }\end{array}$ & $\begin{array}{l}\text { Years } \\
\text { follow- } \\
\text { up }\end{array}$ & $\begin{array}{l}\text { Year surgery/age patient } \\
\text { Surgery/number, location/ size }(\mathrm{mm}) \text { of } n\end{array}$ \\
\hline $166^{*}$ & $F / 1965$ & Yes (10) & $\begin{array}{l}1998 / 21 \\
\text { adenomatosis } \\
\text { largest VII, VIII/ } \\
26 \mathrm{~mm} \\
\text { seg I/ } 28 \mathrm{~mm} \text { (2000) }\end{array}$ & No surgery & & & 13 & $\begin{array}{l}2011 / 46 \\
\mathrm{LH}+\mathrm{I} / 35 \\
+ \text { tumorectomy IVB } / 40 ; \mathrm{VI} / 15\end{array}$ \\
\hline 22 & $F / 1967$ & Yes (10) & $\begin{array}{l}1994 / 27 \\
\text { adenomatosis } \\
3 \text { nodules IV/ 60; } \\
\text { VII/80 } \\
\text { seg I / } 40\end{array}$ & $1994 / 27 / R H+I V$ & $\begin{array}{l}-\mathrm{IV} / 60 \\
-\mathrm{VII} / 80 \\
-\mathrm{V} / 3 \text { little HCA } \\
\text { Micro HCA }\end{array}$ & $\begin{array}{l}3 \text { nodules/ } \\
40 \text { (seg I) }\end{array}$ & 14 & $\begin{array}{l}2008 / 41 \\
\text { seg I/75 } \\
\text { (Increase in size started in 1997, stable since 2008) } \\
2016 \text { (MRI): dysmorphic liver with many small nodules. }\end{array}$ \\
\hline 122 & $F / 1981$ & Yes (10) & $\begin{array}{l}2008 / 27 \\
\text { adenomatosis / LL } \\
/ 150\end{array}$ & $2008 / 27$ / LL + V & $\begin{array}{l}\mathrm{LL} / 150 \\
\mathrm{~V} / 25 \\
+ \text { micro HCA }\end{array}$ & multiple & 7 & $\begin{array}{c}2015 / 34 \\
8 \text { nodules / } 20 \\
\text { VI/ } 15,10\end{array}$ \\
\hline
\end{tabular}

n nodule; RH right hepatectomy; LH left hepatectomy; LL left lobe; RHV right hepatic vein; LHV left hepatic vein

* 2009 endoscopic resection of a colon polyp. 2011 adenocarcinoma sigmoid : resection + chemotherapy. 


\section{Table $4 \mathrm{H}$-HCA adenomatosis growing leading to re-intervention}

\begin{tabular}{|c|c|c|c|c|c|c|c|c|c|c|c|}
\hline & & & $\begin{array}{l}\text { Imaging prior surgery } \\
\text { Number } n \text { and size }(\mathrm{mm})\end{array}$ & \multicolumn{3}{|c|}{ Surgery } & \multicolumn{4}{|c|}{ Follow-up } & \\
\hline \multicolumn{12}{|c|}{ H-HCA } \\
\hline $\begin{array}{l}\text { Patient } \\
\text { ID }\end{array}$ & $\begin{array}{l}\text { Sex / } \\
\text { year of } \\
\text { birth }\end{array}$ & $\begin{array}{l}\text { OC } \\
\text { Yes } \\
\text { (years)/ } \\
\text { No }\end{array}$ & $\begin{array}{l}\text { Date/age patient } \\
\mathrm{n} \text { : number / size } \mathrm{mm}\end{array}$ & $\begin{array}{l}\text { Year surgery/ } \\
\text { age patient / type }\end{array}$ & $\begin{array}{l}\mathrm{n} \text { resection } \\
\text { number/ location / size } \mathrm{mm}\end{array}$ & $\begin{array}{l}\text { Theoretical left } \mathrm{n} \\
\text { location/ size } \mathrm{mm}\end{array}$ & $\begin{array}{l}\text { Years } \\
\text { follow- } \\
\text { up }\end{array}$ & $\begin{array}{l}\mathrm{n} \text { : number/ location/ } \\
\text { size } \\
\text { Prior surgery }\end{array}$ & $\begin{array}{l}2^{\text {nd }} \text { surgery } \\
\text { Year/type }\end{array}$ & $\begin{array}{l}\text { Removed } \mathrm{n} \text { : } \\
\text { number/ size } \\
\mathrm{mm}\end{array}$ & Other \\
\hline 50 & $F / 1972$ & Yes (8) & $\begin{array}{l}2000 / 27 \\
\text { adenomatosis } \\
6 \mathrm{n} \text { visible/ } 35 \\
+1 \mathrm{FNH}\end{array}$ & $\begin{array}{l}2000 / 27 \\
\mathrm{LH}+\mathrm{I}+ \\
\text { tumorectomies }\end{array}$ & $\begin{array}{l}5 \text { and several micro H-HCA } \\
\text { seg } 1 / 60 \text { (hem/necrosis) } \\
\text { LH } 40,10 \\
1 \text { FNH }\end{array}$ & $\begin{array}{l}\text { seg VIII / } 28 \\
\text { VI FNH? HCA? } \\
11 \mathrm{~mm}\end{array}$ & 11 & $\begin{array}{l}\text { In between RHV and } \\
\text { LHV/ } 57\end{array}$ & $\begin{array}{l}2011 \\
\text { tumorectomy }\end{array}$ & $\begin{array}{l}1 / 57 \\
\text { +micro H-HCA }\end{array}$ & $\begin{array}{l}\text { RF 2002, } \\
\text { Thyroid } \\
\text { cancer } \\
2012\end{array}$ \\
\hline 53 & $F / 1952$ & Yes (13) & $\begin{array}{l}2001 / 48 / \\
\text { adenomatosis } \\
\mathrm{VI} / 60 \\
\text { Multiple lesions } \leq 30\end{array}$ & $\begin{array}{l}2001 / 48 \\
\text { VI and IV }\end{array}$ & $\begin{array}{l}\mathrm{VI} / 75 \\
\mathrm{IV} / 25 \\
\text { +micro H-HCA } \\
\text { +micro } \mathrm{n} \text { surface liver }\end{array}$ & $\begin{array}{l}\text { many small } \\
\text { different seg }\end{array}$ & 9 & $5 \mathrm{n}$ from 25 to 60 & $\begin{array}{l}2010 \\
\text { seg III }\end{array}$ & $\begin{array}{l}1 / 60 \\
+ \text { many micro } \\
\mathrm{H}-\mathrm{HCA}\end{array}$ & \\
\hline 82 & $F / 1978$ & No & $\begin{array}{l}2004 / 26 / \\
\text { adenomatosis } \\
\text { hepatomegaly, } \\
\text { limited to the RL }\end{array}$ & $\begin{array}{l}2004 / 26 \\
\mathrm{RH}\end{array}$ & $\begin{array}{l}\text { the whole RL: tumoral } \\
\text { intermingled with NTL } \\
\text { calcifications. } \\
\text { Resection R1 }\end{array}$ & $\begin{array}{l}\text { no tumor in the } \\
\text { left liver }\end{array}$ & 9 & $\begin{array}{l}3 \mathrm{n} \\
2 \text { at the contact with } \\
\text { resected } \mathrm{RH}\end{array}$ & $\begin{array}{l}2013 \\
\text { IV / } 35 \\
\text { nodule seg II }\end{array}$ & $\begin{array}{l}\text { IV / } 35 \\
\text { II / } 7 \\
+ \text { micro H-HCA } \\
\text { NTL }\end{array}$ & \\
\hline 205 & $F / 1971$ & No & $\begin{array}{l}\text { 1986/ } 15 \\
\text { adenomatosis }\end{array}$ & $\begin{array}{l}\text { 1991/20 } \\
\mathrm{RH}+\text { resection LL }\end{array}$ & $\begin{array}{l}1 / 85 \\
+4 n \text { ( } 3 \text { to } 8)\end{array}$ & many small & 23 & $\begin{array}{l}2008 \text { IV /16, 10, } 9 \\
\text { II /14, } 6 \\
2014 \text { seg III }(35 ; 25)\end{array}$ & $\begin{array}{l}2014 \text { / tumorectomies } \\
\mathrm{LL}\end{array}$ & \begin{tabular}{|l|}
37 \\
38 (atypical) \\
+ micro H-HCA \\
\end{tabular} & \\
\hline
\end{tabular}

n nodule; RH right hepatectomy; LH left hepatectomy; LL left lobe; RHV right hepatic vein; LHV left hepatic vein; hem hemorrhage; RF radio frequency; NTL non tumoral liver 